\title{
Compatibility of biological control agents with fungicides against root rot diseases of wheat
}

\section{W. M. Sameer}

Department of Plant Protection, Faculty of Agriculture, Al-Azhar University, Nasr City, Cairo, Egypt

* Corresponding author E-mail: Wael.sameer@azhar.edu.eg (W. Sameer).

\begin{abstract}
Root - rot diseases are considered the most serious diseases of wheat in Egypt, causing a considerable loss seed germination, plant stand and grain yield. The present study aims to evaluate the fungicidal activity of four chemical fungicides and two biological control agents. Four fungicides (i.e. triticonazole, carbendazim, carboxin + thiram and metalaxyl M + fludioxonil) and two biological control agents (i.e. Trichoderma harzianum and Bacillus subtilis) were evaluated separately and their compatibility against two pathogenic fungi, Rhizoctonia solani and Fusarium graminearum that causing root rot diseases of wheat. The in vitro studies showed that the fungicidal activity of the tested fungicides against $R$. solan mycelial growth was descendingly arranged as follows; metalaxyl $\mathrm{M}+$ fludioxonil $>$ carbendazim > triticonazole > carboxin + thiram, while it was metalaxyl $M+$ fludioxonil $>$ triticonazole $>$ carbendazim $>$ carboxin + thiram against $F$. graminearum mycelial growth. In greenhouse trials, the fungicides were applied at 1.5 and $3.0 \mathrm{~g} \mathrm{~kg}^{-1}$ seeds as seed treatment, while biological control agents were applied at 4.5 and $9.0 \mathrm{x}$ $10^{6}$ spores $\mathrm{mL}^{-1}$ water as soil treatment. The results showed that all the treatments significantly reduced disease incidence and increased emergence and plant stands and the biological control agents were the inferior treatments. Generally, the most effective treatments for controlling root rot diseases were metalaxyl M + fludioxonil followed by carbendazim, triticonazole, while the lowest were carboxin + thiram, B. subtilis and T. harzianum as compared with the control treatment. Moreover, the results concluded that the efficiency of T. harzianum and B. subtilis in controlling $R$. solani and $F$. graminearum was obviously enhanced by their compatibility with low rates of the tested fungicides. In conclusion, the biological strategy which used throughout integrated pest management could be improved by using fungicides at low rates.
\end{abstract}

Keywords: Wheat, Root rot; Rhizoctonia solani; Fusarium graminearum; Fungicides and Biological control agents.

\section{INTRODUCTION}

Wheat (Triticum aestivum L.) is one of the most important grain crops in Egypt, where it is used as a basic food grains for humans or as a main source of straw fodder for animal feeding. However, it attacked by many pathogenic organisms under Egyptian conditions. Root - rot diseases are considered the most serious diseases of wheat in Egypt, causing a considerable loss seed germination, plant stand and grain yield. Several soil- borne fungi such as Rhizoctonia solani and Fusarium graminearum cause wheat root rot by invading and colonizing in the root of wheat plants and enter in tissues of wheat seedling (El-Kholy, 1999 and Asran and El-Eraky-Amal, 2011). The fungus $R$. solani causes wheat damping off and root rot diseases (Moubarak and AbdalMonaim, 2011) and caused localized patchy and stunted areas in the field (Ogoshi et al., 1990). Both F. graminearum and F. culmorum are also main soil- borne pathogens that cause root rot, foot rot, stem rot, crown rot and head blight in wheat (Nourozian et al., 2006) which resulted in considerable reduction in agricultural sector economy (Bentley et al., 2006).

Several fungicides either separately as triticonazole (Burlakoti et al., 2010; Kumar et al.,
2017) and carbendazim (Sriraj et al., 2014; Kumar et al., 2017; Manasa et al., 2017; Masiello et al., 2019) or premixed as carboxin + thiram (Akgul and Erkilic, 2016; El-Sayed-Sahar and Abdel-Monaim, 2017; Koycu, 2018) and fludioxonil + metalaxyl (McMullen and Bradley, 2005; Miguel et al., 2015; Akgul and Erkilic, 2016) have been used as seed treatments to control root rot diseases. Application of fungicides is one of the most effective and widely recommended methods of disease control. However, continuous use of such chemical fungicides is not economical and ecofriendly. Also, the repeated use of such fungicides may develop resistant strains of the pathogens (Harman et al., 2004). Therefore, biological control agents can be widely used as alternative tools for controlling root rot diseases. For example, Trichoderma spp. and Bacillus subtilis were found to exhibit significant action against wheat root rot diseases caused by $R$. solani or F. graminearum (Moubarak and Abdel-Monaim, 2011; El-Ballat, 2017 and Ishtiaq et al., 2019).

To develop an effective disease management program, the compatibility of potential biological control agents with low fungicide rates is essential (Wedajo, 2015). Several researchers stated that the combination 
of chemical fungicides with biological control agents including Trichoderma spp. (Jensen et al., 2002; Wang et al., 2005; Thoudam and Dutta, 2014; Wedajo, 2015; Dhanya et al., 2016) and Bacillus subtilis (Jensen et al., 2002; Basamma and Kulkarni, 2017; Rajkumar et al., 2018) may increase and enhance disease control rates and provide better management of soil- and seedborne diseases.

Considering all these points the present study was conducted to evaluate the fungicidal activity of four chemical fungicides and two biological control agents when used separately or in combinations for controlling root rot diseases of wheat caused by $R$. solani and $F$. graminearum.

\section{MATERIALS AND METHODS}

Laboratory and greenhouse experiments were conducted at the Department of Plant Protection, Faculty of Agriculture, Al-Azhar University, Nasr City, Cairo, Egypt.

\section{Isolation and identification of the causal} organisms:

Pure isolates of Rhizoctonia solani and Fusarium graminearum, obtained from wheat roots showing typical symptoms of root rot disease. Transverse sections of the wheat roots collected from the field were surface sterilized by $0.5 \%$ sodium hypochlorite for $1 \mathrm{~min}$., rinsed in sterilized distilled water and drained on paper towels. They were transferred on PDA medium in Petri dishes, each contained 3 pieces and replicated 3 times. The dishes were incubated at $27^{\circ} \mathrm{C}$ for 5 days. The growing fungi were subcultured on PDA slants. Single spore technique was used for purification of the isolated fungi. The isolated fungi were identified in Department of Botany, Branch of Plant Pathology, Faculty of Agriculture, AlAzhar University, Nasr City, Cairo, Egypt.

\section{Experimental materials:}

The wheat (Triticum aestivum L.) seeds, (Gemiza $9 \mathrm{cv}$.) were obtained from the Wheat Research Department, Agriculture Research Center, Ministry of Agriculture and Land Reclamation.

\section{Fungicides and Biological control agents:}

Four chemical fungicides, triticonazole (Premis $2.5 \%$ F.S.), carbendazim (Kemazed 50 \% W.P.), carboxin + thiram (Vitavax 75 \%W.P.) and metalaxyl M+fludioxonil (Maxim XL 3.5\% F.S.) and two biological control agents, Plantguard (The fungus Trichoderma harzianum each one $\mathrm{cm}^{3}$ of the liquid contain 30 million organisms) and Rhizo- N (The bacterium
Bacillus subtilis each one $\mathrm{g}$ powder contain 30 million organisms) were evaluated against the two pathogenic fungi.

\section{In vitro sensitivity tests:}

Sensitivity of $R$. solani and F. graminearum to the tested fungicides was evaluated according to Frisina and Benson (1988). The fungicides were diluted in sterile distilled water, then added to cooled PDA medium at concentrations of $0.01,0.05,0.1,0.5,1.0,5.0$, 10.0, 50.0, and $100.0 \mu \mathrm{g}$ a.i. $\mathrm{mL}^{-1}$ for each fungicide. The poisoned media were poured in plates $(9 \mathrm{~cm}$ diameter), other plates containing fungicide - free medium were used as control treatment. The medium was seeded by $0.4 \mathrm{~cm}$ diameter disk, removed from 7-day-old culture of the fungus, on solidified medium and incubated for 7 days at $25^{\circ} \mathrm{C}$. Each treatment was replicated four times. Growth on the fungicides amended medium was determined by measuring the colony diameter $(\mathrm{cm})$. The percentage of growth inhibition was calculated relative to the control treatment. The concentration giving $50 \%$ linear growth inhibition (EC50) was determined by regression analysis of the $\log$ probit transformed data (Finney, 1971).

\section{Pot experiments:}

\section{Soil infestation:}

To prepare inocula required for the test, the isolates of $R$. solani and F. graminearum were grown in $500 \mathrm{ml}$ conical flask contained barley grains medium. The used soil (clay loamy), was air dried, sieved and packed in some polyethylene bags which were steamed in an autoclave until a temperature of $100{ }^{\circ} \mathrm{C}(1.3-1.4$ pressure) was reached and then holding the temperature at $90-110{ }^{\circ} \mathrm{C}$ (1.1-1.4 pressure) for one hour (Knudsen and Bin, 1990). The inoculum of each fungus was incorporated into the autoclaved soil at the level of $5 \% \mathrm{~W} / \mathrm{W}$ and thoroughly mixed. Plastic pots $(20 \mathrm{~cm}$ in diameter), which were previously sterilized by $5 \%$ formalin solution, were filled with infested soil, except control without infestation (the same amount of the sterile barely grains without fungus). All pots were daily irrigated for 7 days to stimulate the fungal growth and to ensure its distribution within the soil before cultivation.

\section{Fungicidal seed and biocontrol treatments:}

This trial was carried out to investigate the efficiency of fungicides at two rates (as seed treatment) and biological agents at two concentrations (as soil treatment) separately and the compatibility of fungicides at the low 
rate with biological control agents for controlling the incidence of artificial infection with Rhizoctonia and Fusarium root rot on wheat growing in pots under greenhouse conditions. Seeds were treated with the tested fungicides (1.5 and 3.0 g product $\mathrm{kg}^{-1}$ seeds) according to Warhman et al., (1989) with some modification. The appropriate amounts of the tested fungicides were placed in plastic bags, seeds were added, then a few drops of $5 \%$ animal glue solution were added and shaken by the hand until the seeds were uniformly covered by the chemical. Treated seeds were then dried at room temperature for $24 \mathrm{~h}$ before planting. Biological control treatments were carried out by adding spore suspension $\left(10 \mathrm{~mL} \mathrm{pot}^{-1}\right)$ of the biological agent, at concentrations of 4.5 and 9.0 $\times 10^{6}$ spore $\mathrm{mL}^{-1}$ water on the surface of infested soil.

The experiments were designed as follows: 1- Fungicide- free seeds in non-infested soil.

2- Fungicide- free seeds in soil infested with $R$. solani or F. graminearum.

3- Fungicide- treated seeds in soil infested with $R$. solani or F. graminearum.

4-Fungicide- free seeds in soil infested with $R$. solani or F. graminearum and biological agent.
5-Fungicide -treated seeds in soil infested with $R$. solani or F. graminearum and biological agent.

Each pot was planted with 15 wheat seeds and each treatment was replicated four times. Pre- and post- emergence damping -off \% were recorded after 14 and 42 days from sowing, respectively, and the survival plants were recorded at the end of the experiment.

\section{RESULTS AND DISCUSSION}

\section{In vitro activity of the fungicides on the isolated fungi}

The in vitro sensitivity of $R$. solani and $F$. graminearum to four fungicides was determined. The $\mathrm{EC}_{50}$ values of the tested fungicides are listed in Table (1). Based on the EC50 values, the isolates of $R$. solani and $F$. graminearum are considered to be more sensitive to metalaxyl $\mathrm{M}+$ fludioxonil $\left(\mathrm{EC}_{50}=\right.$ 0.24 and $0.32 \mu$ g a.i. $\mathrm{mL}^{-1}$, respectively) followed by carbendazim $\left(\mathrm{EC}_{50}=0.59\right.$ and $1.763 \mu \mathrm{g}$ a.i. $\mathrm{mL}^{-1}$, respectively) and triticonazole $\left(\mathrm{EC}_{50}=1.58\right.$ and $1.32 \mu \mathrm{g}$ a.i. $\mathrm{mL}^{-1}$, respectively). However, the $\mathrm{EC}_{50}$ values for carboxin + thiram were considerably higher $\left(\mathrm{EC}_{50}=8.39\right.$ and $29.43 \mu \mathrm{g}$ a.i. $\mathrm{mL}^{-1}$, respectively), indicating less sensitivity of the fungi.

Table 1. $\mathrm{EC}_{50}{ }^{*}$ values $\left(\mu \mathrm{g}\right.$ a.i. $\mathrm{mL}^{-1}$ ) of the tested fungicides against mycelial growth of Rhizoctonia solani and Fusarium graminearum grown on PDA medium.

\begin{tabular}{|c|c|c|}
\hline Fungicides & Rhizoctonia solani & Fusarium graminearum \\
\hline Triticonazole & 1.58 & 1.32 \\
\hline Carbendazim & 0.59 & 1.763 \\
\hline Carboxin + thiram & 8.39 & 29.43 \\
\hline $\begin{array}{l}\text { Metalaxyl M + } \\
\text { fludioxonil }\end{array}$ & 0.24 & 0.32 \\
\hline
\end{tabular}

Data listed in Table (1) show the efficacies of the tested fungicides against both $R$. solani and F. graminearum under laboratory condition. The obtained results were previously confirmed by other researchers. For example, El-Kholy (1999) found that the $\mathrm{EC}_{50}$ values of triticonazole were 1.10 and $0.90 \mu \mathrm{g} \mathrm{mL}^{-1}$ against mycelial growth of $R$. solani and F. graminearum, respectively. Also, the $\mathrm{EC}_{50}$ values of triticonazole for isolates of F. graminearum ranged from 0.043 to $4.965 \mu \mathrm{g}$ $\mathrm{mL}^{-1}$ (Burlakoti et al., 2010). Similarly, carbendazim effectively inhibited the mycelial growth and sclerotial production of $R$. solani at lower concentration (Sriraj et al., 2014; Kumar et al., 2017). Also, mycelial growth of $F$. graminearum was strongly inhibited by carbendazim (Ivic et al., 2011). Carboxin + thiram fungicide exhibited a moderate effect against the growth of $R$. solani and it was less effective against $F$. graminearum growth (Table $1)$. These findings were confirmed by El-Ballat (2017) who found that the EC50 values of carboxin + thiram to $R$. solani and $F$. graminearum were 4.50 and $54.0 \mu \mathrm{g} \mathrm{mL}-1$, respectively. On the other hand, the results in the same table showed high efficacies of metalaxyl M + fludioxonil against both $R$. solani and $F$. graminearum under laboratory condition. These results are in accordance with those obtained previously (McMullen and Bradley, 2005; Miguel et al., 2015; Akgul and Erkilic, 2016). Sameer (2018) found that $R$. solani and $F$. graminearum were sensitive to fludioxonil with $\mathrm{EC}_{50}$ values of 0.29 and $0.371 \mu \mathrm{g} \mathrm{mL}-1$, respectively. 


\section{Greenhouse pot experiments}

Separately effect of the tested fungicides and bioagents on damping-off diseases caused by $R$. solani and F. graminearum.

The effects of the tested fungicides applied at 1.5 and $3.0 \mathrm{~g} \mathrm{~kg}^{-1}$ seeds (as seed treatment) and biological control agents applied at 4.5 and
$9.0 \times 10^{6}$ spores $\mathrm{mL}^{-1}$ (as soil treatment) on preand post- emergence damping- off diseases of wheat caused by $R$. solani and F. graminearum are listed in Table (2). The incidence of pre- and post- emergence of untreated seeds and soil were 40.00 and $33.33 \%$, respectively, for $R$. solani and were 33.33 and $42.50 \%$, respectively, for F. graminearum.

Table 2. Separately effects of the tested fungicides and bioagents against Rhizoctonia solani and Fusarium graminearum on wheat growing under greenhouse conditions.

\begin{tabular}{|c|c|c|c|c|c|c|c|}
\hline \multirow[t]{3}{*}{ Treatments } & \multirow{3}{*}{$\begin{array}{c}\text { Rate of } \\
\text { application } \\
\text { (g kg-1 seeds) } \\
\text { or } \\
\text { (spores } \mathrm{mL}^{-1} \\
\text { water) }\end{array}$} & \multirow{2}{*}{\multicolumn{3}{|c|}{$\begin{array}{c}\text { Rhizoctonia solani } \\
\text { average } \% \text { of }\end{array}$}} & \multicolumn{3}{|c|}{ Fusarium graminearum } \\
\hline & & & & & \multicolumn{3}{|c|}{ average $\%$ of } \\
\hline & & $\begin{array}{c}\text { Pre- } \\
\text { emergence } \\
\text { damping - } \\
\text { off }\end{array}$ & $\begin{array}{c}\text { Post- } \\
\text { emergence } \\
\text { damping - } \\
\text { off }\end{array}$ & $\begin{array}{c}\text { Plant } \\
\text { survivals }\end{array}$ & $\begin{array}{c}\text { Pre- } \\
\text { emergence } \\
\text { damping - } \\
\text { off }\end{array}$ & $\begin{array}{c}\text { Post- } \\
\text { emergence } \\
\text { damping- } \\
\text { off }\end{array}$ & $\begin{array}{c}\text { Plant } \\
\text { survivals }\end{array}$ \\
\hline Control $(1)^{*}$ & & 5.00 & 3.51 & 91.67 & 5.00 & 3.51 & 91.67 \\
\hline Control $(2)^{* *}$ & & 40.00 & 33.33 & 40.00 & 33.33 & 42.50 & 38.33 \\
\hline \multirow[t]{2}{*}{ Triticonazole } & 1.50 & 21.67 & 12.77 & 68.33 & 16.67 & 18.00 & 68.33 \\
\hline & 3.00 & 11.67 & 11.32 & 78.33 & 10.00 & 9.26 & 81.67 \\
\hline \multirow[t]{2}{*}{ Carbendazim } & 1.50 & 20.00 & 12.50 & 70.00 & 16.67 & 22.00 & 65.00 \\
\hline & 3.00 & 10.00 & 9.26 & 81.67 & 6.67 & 10.71 & 83.33 \\
\hline Carboxin + & 1.50 & 25.00 & 17.78 & 61.67 & 25.00 & 28.89 & 53.33 \\
\hline thiram & 3.00 & 16.67 & 14.00 & 71.67 & 16.67 & 20.00 & 66.67 \\
\hline Metalaxyl M + & 1.50 & 13.33 & 11.54 & 76.67 & 10.00 & 12.96 & 78.33 \\
\hline fludioxonil & 3.00 & 5.00 & 3.51 & 91.67 & 3.33 & 6.90 & 90.00 \\
\hline Trichoderma & $4.5 \times 10^{6}$ & 31.67 & 29.27 & 48.33 & 28.33 & 32.56 & 48.33 \\
\hline harzianum & $9.0 \times 10^{6}$ & 25.00 & 24.44 & 56.67 & 20.00 & 20.83 & 63.33 \\
\hline \multirow[t]{2}{*}{ Bacillus subtilis } & $4.5 \times 10^{6}$ & 31.67 & 26.83 & 50.00 & 26.67 & 31.82 & 50.00 \\
\hline & $9.0 \times 10^{6}$ & 20.00 & 20.83 & 63.33 & 18.33 & 18.37 & 66.67 \\
\hline \multirow[t]{3}{*}{ L.S.D. at $5 \%$} & $\begin{array}{l}\text { Treatments } \\
\text { (T.) }\end{array}$ & 2.97 & 2.59 & 3.76 & 3.26 & 3.19 & 4.18 \\
\hline & Rates (R.) & 1.88 & 2.04 & 2.17 & 1.88 & 1.67 & 3.26 \\
\hline & T. $\times$ R. & 3.29 & 3.51 & 4.19 & 4.08 & 4.31 & 5.22 \\
\hline
\end{tabular}

Results indicated that all the tested fungicides and biological control agents were able to control damping-off caused by both fungi, and fungicides were the superior treatments. Metalaxyl M + fludioxonil was the most effective fungicide tested, followed by carbendazim and triticonazole, but carboxin + thiram was the least effective. Trichoderma harzianum was inferior to Bacillus subtilis against $R$. solani and F. graminearum. It was noticed that increasing the application rate of the tested fungicides and bioagents resulted in enhancing their efficiencies against the pathogenic fungi with increasing the growing plants. Results showed that the high rate of triticonazole, carbendazim, carboxin + thiram, metalaxyl M + fludioxonil, $T$. harzianum and $B$. subtilis gave $78.33,81.67,71.67,91.67,56.67$ and $63.33 \%$ plant survivals, respectively, for $R$. solani and gave $81.67,83.33,66.67,90.00,63.33$ and $66.67 \%$ plant survivals, respectively, for F. graminearum. The L.S.D. values for treatments in Table (2) revealed that metalaxyl $M+$ fludioxonil significantly raised the plant survivals over all fungicidal treatments. The statistical analysis showed that the difference between carbendazim and triticonazole was not significant. The results showed that carboxin + thiram fungicide was the least effective one. Also, there was no significant difference between carboxin + thiram and B. subtilis in case of $F$. graminearum, but there was significant in case of $R$. solani. The statistical analysis also showed that the difference between $B$. subtilis and T. harzianum was not significant in both pathogenic fungi, but significant only at higher concentration in case of $R$. solani. Also, the statistical analysis showed that the difference between the efficiency of the two applied rates or concentrations was highly significant in all treatments.

Our present results are in agreement with those obtained previously. For example, El- 
Kholy (1999) found that triticonazole was effective in reducing the Rhizoctonia and Fusarium root rot incidence on wheat plants under greenhouse conditions and increased emergence and plant stands. Burlakoti et al. (2010) suggested that triticonazole has the potential to control Fusarium diseases in field conditions if applied in a timely manner. Carbendazim was effective against $R$. solani at the lowest concentration by maximum inhibiting the mycelial growth and sclerotia formation (Sriraj et al., 2014; Kumar et al., 2017). Also, carbendazim has been widely used to control Fusarium diseases on several crops including wheat, showing a great capability to prevent Fusarium infections (Manasa et al., 2017; Mannai et al., 2018). In field trials, triazole and benzimidazole carbamate fungicides were confirmed to be effective to reduce $F$. graminearum contamination (Masiello et al., 2019). Carboxin + thiram, was among fungicides tested by El-Ballat (2017) who found that this fungicide was effective against Rhizoctonia and Fusarium root rot of wheat. Fludioxonil used alone or in mixture with metalaxyl $\mathrm{M}$, has been largely used for cereals seed treatments, showing a high efficacy against Rhizoctonia and Fusarium root rot diseases (Miguel et al., 2015; Soovali et al., 2017). Akgul and Erkilic (2016) found that tebuconazole, carboxin + thiram and metalaxyl $\mathrm{M}+$ fludioxonil used as seed treatments had significant effects on Fusarium foot rot disease of wheat by penetrate wheat seeds and can be transported from the seeds to the shoots.

A large number of plant diseases have been successfully controlled through fungal and bacterial antagonists (El-Ballat, 2017; Ishtiaq et al., 2019). El-Sayed-Sahar and Abdel-Monaim (2017) reported that biological control agents significantly reduced the disease severity of root rot diseases caused by Rhizoctonia and Fusarium. They found that B. subtilis was the most effective bioagents followed by $T$. harzianum. The biological control agents secreted enzymes and secondary metabolites in wheat plants and induced systemic disease resistance against $R$. solani and $F$. graminearum (Ishtiaq et al., 2019).

\section{Combined effect of T. harzianum and fungicides on wheat damping-off diseases caused by $R$. solani and F. graminearum.}

Results in Table (3) reveal that T. harzianum moderately controlled the pathogens and then increased the percent of plant survivals which recorded $48.33 \%$ for both pathogenic fungi when $4.5 \times 10^{6}$ spores $\mathrm{mL}^{-1}$ of $T$. harzianum were used. However, when T. harzianum was applied at $9.0 \times 10^{6}$ spores $\mathrm{mL}^{-1}$, the percent of plant survivals were 56.67 and $63.33 \%$ with $R$. solani and $F$. graminearum, respectively.

The combined fungicidal activity of $T$. harzianum at 4.5 and $9.0 \times 10^{6}$ spores $\mathrm{mL}^{-1}$ with the tested fungicides at $1.5 \mathrm{~g}_{\text {product }} \mathrm{kg}^{-1}$ seeds against pre- and post-emergence damping off diseases caused by $R$. solani and F. graminearum was evaluated. Results in Table (3) indicate that application of fungicides with $T$. harzianum gave considerable control for $R$. solani and $F$. graminearum and increased the percent of plant survivals. The results indicated that $T$. harzianum $\left(9.0 \times 10^{6}\right.$ spores $\left.\mathrm{mL}^{-1}\right)$ with metalaxyl $\mathrm{M}+$ fludioxonil (1.5 $\mathrm{g} \mathrm{kg}^{-1}$ seeds) gave a high percentage of plant survivals. Application of $T$. harzianum at high concentration with carbendazim (1.5 $\mathrm{g} \mathrm{kg}^{-1}$ seeds) improved the activity of T. harzianum and did not improve the activity of carbendazim. T. harzianum at $9.0 \times$ $10^{6}$ spores $\mathrm{mL}^{-1}$ and the fungicide carboxin + thiram at $1.5 \mathrm{~g} \mathrm{~kg}^{-1}$ seeds gave 56.67 and 61.67 $\%$ plant survivals, respectively for controlling R. solani and gave 63.33 and $53.33 \%$ plant survivals, respectively, for controlling $F$. graminearum when they were used alone. However, application of $T$. harzianum with carboxin + thiram at the same rates increased plant survivals to 73.33 and $66.67 \%$ for controlling $R$. solani and $F$. graminearum, respectively. The statistical analysis showed that the application of fungicide with $T$. harzianum significantly differed from that of bioagent applied separately. The results indicated that application of T. harzianum as soil treatment with fungicides as seed treatment improved the antagonistic action against preand post- emergence damping off.

The obtained results indicated that low rates of triticonazole, carboxin + thiram and metalaxyl $\mathrm{M}+$ fludioxonil could control diseases of wheat, caused by R. solani and F. graminearum, in the presence of $T$. harzianum which is resistant to these fungicides. Previous results proposed that application of fungicide may metabolically weaken the pathogen and make it vulnerable to potent antagonists (Viji et al., 1997). Naar and Kecskes (1998) reported that the tolerant bioagents exhibited greater antagonism with the addition of fungicides. Also, the application of fungicides with bioagents would provide similar disease suppression as achieved with higher fungicide use (Monte, 2001). Trichoderma has the ability to degrade xenobiotic compounds and can live in environments with residues of fungicides (Chaparro et al., 2011). Tapwal et al., (2012) 
Table 3. Greenhouse activity of Trichoderma harzianum on Rhizoctonia solani and Fusarium graminearum in the presence of different fungicides.

\begin{tabular}{|c|c|c|c|c|c|c|c|c|c|}
\hline \multirow{4}{*}{$\begin{array}{c}\text { Fungicides at low } \\
\text { rate } \\
\left(1.5 \mathrm{~g} \mathrm{~kg}^{-1} \text { seeds }\right)\end{array}$} & \multirow{2}{*}{\multicolumn{3}{|c|}{ Separated fungicide }} & \multicolumn{6}{|c|}{ Fungicide + Trichoderma harzianum at } \\
\hline & & & & \multirow{2}{*}{\multicolumn{3}{|c|}{$\begin{array}{c}4.5 \times 10^{6} \text { spores } \mathrm{mL}^{-1} \\
\text { average } \% \text { of }\end{array}$}} & \multirow{2}{*}{\multicolumn{3}{|c|}{$\begin{array}{c}9.0 \times 10^{6} \text { spores } \mathrm{mL}^{-1} \\
\text { average } \% \text { of }\end{array}$}} \\
\hline & \multicolumn{3}{|c|}{ average $\%$ of } & & & & & & \\
\hline & $\begin{array}{c}\text { Pre- } \\
\text { emergence } \\
\text { damping - } \\
\text { off }\end{array}$ & $\begin{array}{c}\text { Post- } \\
\text { emergence } \\
\text { damping - } \\
\text { off }\end{array}$ & $\begin{array}{c}\text { Plant } \\
\text { survivals }\end{array}$ & $\begin{array}{c}\text { Pre- } \\
\text { emergence } \\
\text { damping - } \\
\text { off }\end{array}$ & $\begin{array}{c}\text { Post- } \\
\text { emergence } \\
\text { damping - } \\
\text { off }\end{array}$ & $\begin{array}{c}\text { Plant } \\
\text { survivals }\end{array}$ & $\begin{array}{c}\text { Pre- } \\
\text { emergence } \\
\text { damping - } \\
\text { off }\end{array}$ & $\begin{array}{c}\text { Post- } \\
\text { emergence } \\
\text { damping - } \\
\text { off } \\
\end{array}$ & $\begin{array}{c}\text { Plant } \\
\text { survivals }\end{array}$ \\
\hline Control $(1)^{*}$ & 5.00 & 3.51 & 91.67 & - & - & - & - & - & - \\
\hline $\begin{array}{l}\text { Control }(2)^{* *} \\
\text { R. solani }\end{array}$ & 40.00 & 33.33 & 40.00 & 31.67 & 29.27 & 48.33 & 25.00 & 24.44 & 56.67 \\
\hline Triticonazole & 21.67 & 12.77 & 68.33 & 20.00 & 12.50 & 70.00 & 18.33 & 10.20 & 73.33 \\
\hline Carbendazim & 20.00 & 12.50 & 70.00 & 20.00 & 12.50 & 70.00 & 18.33 & 12.24 & 71.67 \\
\hline Carboxin + thiram & 25.00 & 17.78 & 61.67 & 21.67 & 14.89 & 66.67 & 18.33 & 10.20 & 73.33 \\
\hline $\begin{array}{l}\text { Metalaxyl M + } \\
\text { fludioxonil }\end{array}$ & 13.33 & 11.54 & 76.67 & 10.00 & 7.41 & 83.33 & 8.33 & 5.45 & 86.67 \\
\hline L.S.D. at $5 \%$ & \multicolumn{3}{|c|}{ Pre-emergence damping -off } & \multicolumn{3}{|c|}{ Post-emergence damping -off } & \multicolumn{3}{|c|}{ Plant survivals } \\
\hline Treatments (T.) & \multicolumn{3}{|c|}{3.13} & \multicolumn{3}{|c|}{2.86} & \multicolumn{3}{|c|}{3.55} \\
\hline Rates (R.) & \multirow{2}{*}{\multicolumn{3}{|c|}{$\begin{array}{l}1.89 \\
4.23\end{array}$}} & \multirow{2}{*}{\multicolumn{3}{|c|}{$\begin{array}{l}1.67 \\
4.08\end{array}$}} & \multicolumn{3}{|c|}{2.18} \\
\hline T. $\times$ R. & & & & & & & \multicolumn{3}{|c|}{4.66} \\
\hline Control $(1)^{*}$ & \multicolumn{3}{|c|}{$\frac{35}{351}$} & - & - & - & - & - & - \\
\hline $\begin{array}{l}\text { Control (2)** } \\
\text { F.graminearum }\end{array}$ & 33.33 & 42.50 & 38.33 & 28.33 & 32.56 & 48.33 & 20.00 & 20.83 & 63.33 \\
\hline Triticonazole & 16.67 & 18.00 & 68.33 & 15.00 & 15.69 & 71.67 & 15.00 & 11.67 & 75.00 \\
\hline Carbendazim & 16.67 & 22.00 & 65.00 & 18.33 & 20.41 & 65.00 & 16.67 & 18.00 & 68.33 \\
\hline Carboxin + thiram & 25.00 & 28.89 & 53.33 & 20.00 & 25.00 & 60.00 & 18.33 & 18.36 & 66.67 \\
\hline $\begin{array}{l}\text { Metalaxyl M + } \\
\text { fludioxonil }\end{array}$ & 10.00 & 12.96 & 78.33 & 6.67 & 10.71 & 83.33 & 5.00 & 5.26 & 90.00 \\
\hline L.S.D. at $5 \%$ & \multicolumn{3}{|c|}{ Pre-emergence damping -off } & \multicolumn{3}{|c|}{ Post-emergence damping -off } & \multicolumn{3}{|c|}{ Plant survivals } \\
\hline Treatments (T.) & \multirow{2}{*}{\multicolumn{3}{|c|}{$\begin{array}{l}3.41 \\
200\end{array}$}} & \multicolumn{3}{|c|}{3.39} & \multicolumn{3}{|c|}{4.19} \\
\hline Rates (R.) & & & & \multirow{2}{*}{\multicolumn{3}{|c|}{$\begin{array}{l}1.89 \\
4.05\end{array}$}} & \multirow{2}{*}{\multicolumn{3}{|c|}{$\begin{array}{l}2.58 \\
5.04\end{array}$}} \\
\hline T. $\times$ R. & \multicolumn{3}{|c|}{4.37} & & & & & & \\
\hline
\end{tabular}

suggested that fungicides can be compatible with Trichoderma to control soil-borne plant pathogens. Trichoderma spp. were found to be compatible with triazole fungicides such as triticonazole (Thoudam and Dutta, 2014), thiram (Bagwan, 2010), carboxin (Rubayat and Alam Bhuiyan, 2012), carboxin + thiram (Jensen et al., 2002) and fludioxonil (Wang et al., 2005) for controlling root rot diseases. Wang et al. (2005) suggested that fludioxonil and Trichoderma could be integrated into a disease management program for Fusarium root rot.

Results in Table (3) also indicated that application of T. harzianum with carbendazim enhanced the activity of $T$. harzianum and did not improve the fungicide. This result was confirmed by (Rubayat and Alam Bhuiyan, 2012; Tapwal et al., 2012; Thoudam and Dutta, 2014) who found that Trichoderma was incompatible with carbendazim.

\section{Combined effect of B. subtilis and fungicides on wheat damping-off diseases caused by $R$. solani and $F$. graminearum.}

B. subtilis at 4.5 and $9.0 \times 10^{6}$ spores $\mathrm{mL}^{-1}$ (as soil treatment) and fungicide at $1.5 \mathrm{~g} \mathrm{~kg}^{-1}$ seeds (as seed treatment) were evaluated separately and in combinations for controlling pre- and post- emergence damping - off caused by $R$. solani and F. graminearum. Results in Table (4) reveal that the bioagent moderately controlled the pathogens and consequently increased the percent of plant survivals. The results in Table (4) indicated that when the bioagent $B$. subtilis was applied at $4.5 \times 10^{6}$ spores $\mathrm{mL}^{-1}$ for controlling the two pathogens $R$. solani and F. graminearum, it resulted in $50.00 \%$ plant survivals for both pathogens, but when used at $9.0 \times 10^{6}$ spores $\mathrm{mL}^{-1}$, the corresponding plant survivals rates were 63.33 and $66.67 \%$, respectively. 
Table 4. Greenhouse activity of Bacillus subtilis on Rhizoctonia solani and Fusarium graminearum in the presence of different fungicides.

\begin{tabular}{|c|c|c|c|c|c|c|c|c|c|}
\hline \multirow{4}{*}{$\begin{array}{c}\text { Fungicides at low } \\
\text { rate } \\
\left(1.5 \mathrm{~g} \mathrm{~kg}^{-1} \text { seeds }\right)\end{array}$} & \multirow{2}{*}{\multicolumn{3}{|c|}{ Separated fungicide }} & \multicolumn{6}{|c|}{ Fungicide + Bacillus subtilis at } \\
\hline & & & & \multirow{2}{*}{\multicolumn{3}{|c|}{$\begin{array}{c}4.5 \times 10^{6} \text { spores } \mathrm{mL}^{-1} \\
\text { average } \% \text { of }\end{array}$}} & \multicolumn{3}{|c|}{$9.0 \times 10^{6}$ spores $\mathrm{mL}^{-1}$} \\
\hline & \multicolumn{3}{|c|}{ average $\%$ of } & & & & & average $\%$ & \\
\hline & $\begin{array}{c}\text { Pre- } \\
\text { emergence } \\
\text { damping - } \\
\text { off }\end{array}$ & $\begin{array}{l}\text { Post- } \\
\text { emergence } \\
\text { damping - } \\
\text { off }\end{array}$ & $\begin{array}{r}\text { Plant } \\
\text { survivals }\end{array}$ & $\begin{array}{c}\text { Pre- } \\
\text { emergence } \\
\text { damping - } \\
\text { off }\end{array}$ & $\begin{array}{l}\text { Post- } \\
\text { emergence } \\
\text { damping - } \\
\text { off }\end{array}$ & $\begin{array}{c}\text { Plant } \\
\text { survivals }\end{array}$ & $\begin{array}{c}\text { Pre- } \\
\text { emergence } \\
\text { damping - } \\
\text { off }\end{array}$ & $\begin{array}{l}\text { Post- } \\
\text { emergence } \\
\text { damping - } \\
\text { off }\end{array}$ & $\begin{array}{c}\text { Plant } \\
\text { survivals }\end{array}$ \\
\hline Control $(1)^{*}$ & 5.00 & 3.51 & 91.67 & - & - & - & - & - & - \\
\hline $\begin{array}{l}\text { Control (2)** } \\
\text { R. solani }\end{array}$ & 40.00 & 33.33 & 40.00 & 31.67 & 26.83 & 50.00 & 20.00 & 20.83 & 63.33 \\
\hline Triticonazole & 21.67 & 12.77 & 68.33 & 18.33 & 10.20 & 73.33 & 15.00 & 9.80 & 76.67 \\
\hline Carbendazim & 20.00 & 12.50 & 70.00 & 16.67 & 8.00 & 76.67 & 11.67 & 7.54 & 81.67 \\
\hline Carboxin + thiram & 25.00 & 17.78 & 61.67 & 20.00 & 14.58 & 68.33 & 18.33 & 10.20 & 73.33 \\
\hline $\begin{array}{c}\text { Metalaxyl M + } \\
\text { fludioxonil }\end{array}$ & 13.33 & 11.54 & 76.67 & 8.33 & 7.27 & 85.00 & 5.00 & 5.26 & 90.00 \\
\hline L.S.D. at $5 \%$ & \multicolumn{3}{|c|}{ Pre-emergence damping -off } & \multicolumn{3}{|c|}{ Post-emergence damping -off } & \multicolumn{3}{|c|}{ Plant survivals } \\
\hline Treatments (T.) & \multicolumn{3}{|c|}{3.16} & \multicolumn{3}{|c|}{2.74} & \multicolumn{3}{|c|}{4.89} \\
\hline Rates (R.) & \multirow{2}{*}{\multicolumn{3}{|c|}{$\begin{array}{l}1.98 \\
4.52\end{array}$}} & \multirow{2}{*}{\multicolumn{3}{|c|}{$\begin{array}{l}1.60 \\
4.33\end{array}$}} & \multicolumn{3}{|c|}{$\begin{array}{l}3.39 \\
5.79\end{array}$} \\
\hline T. $x$ R. & & & & & & & \multicolumn{3}{|c|}{5.79} \\
\hline Control $(1)^{*}$ & 5.00 & 3.51 & 91.67 & \multicolumn{2}{|r|}{-} & - & - & - & - \\
\hline $\begin{array}{c}\text { Control }(2)^{* *} \\
\text { F.graminearum }\end{array}$ & 33.33 & 42.50 & 38.33 & 26.67 & 31.82 & 50.00 & 18.33 & 18.37 & 66.67 \\
\hline Triticonazole & 16.67 & 18.00 & 68.33 & 13.33 & 15.38 & 73.33 & 10.00 & 9.26 & 81.67 \\
\hline Carbendazim & 16.67 & 22.00 & 65.00 & 11.67 & 13.21 & 76.67 & 6.67 & 7.14 & 86.67 \\
\hline Carboxin + thiram & 25.00 & 28.89 & 53.33 & 18.33 & 20.41 & 65.00 & 13.33 & 11.54 & 76.67 \\
\hline $\begin{array}{c}\text { Metalaxyl M + } \\
\text { fludioxonil }\end{array}$ & 10.00 & 12.96 & 78.33 & 8.33 & 9.09 & 85.00 & 5.00 & 3.51 & 91.67 \\
\hline L.S.D. at $5 \%$ & \multicolumn{3}{|c|}{ Pre-emergence damping -off } & \multicolumn{3}{|c|}{ Post-emergence damping -off } & \multicolumn{3}{|c|}{ Plant survivals } \\
\hline Treatments (T.) & \multicolumn{3}{|c|}{3.22} & \multicolumn{3}{|c|}{3.19} & \multicolumn{3}{|c|}{4.31} \\
\hline Rates (R.) & \multirow{2}{*}{\multicolumn{3}{|c|}{$\begin{array}{l}2.03 \\
4.09\end{array}$}} & \multicolumn{3}{|c|}{2.07} & \multicolumn{3}{|c|}{2.53} \\
\hline T. $x$ R. & & & & \multicolumn{3}{|c|}{4.16} & \multicolumn{3}{|c|}{5.17} \\
\hline
\end{tabular}

Results in Table (4) indicated that the usage of fungicides as seed treatments with $B$. subtilis as soil treatment considerably controlled $R$. solani and F. graminearum which resulted in increased plant survivals rates. For example, the usage of $B$. subtilis $\left(9.0 \times 10^{6}\right.$ spores $\left.\mathrm{mL}^{-1}\right)$ with metalaxyl M + fludioxonil (1.5 $\mathrm{g} \mathrm{kg}^{-1}$ seeds) gave high plant survivals rates. When $B$. subtilis at $9.0 \times 10^{6}$ spores $\mathrm{mL}^{-1}$ and carbendazim at 1.5 $\mathrm{g} \mathrm{kg}^{-1}$ seeds were used separately, they gave 63.33 and $70.00 \%$ plant survivals, respectively, for controlling $R$. solani and gave 66.67 and $65.00 \%$ plant survivals, respectively, for controlling F. graminearum. However, application of $B$. subtilis with carbendazim at the same rates increased plant survivals to 81.67 and $86.67 \%$ for controlling root rot diseases caused by $R$. solani and F. graminearum, respectively. These results indicated that $B$. subtilis was compatible with all fungicides. The results obtained are in agreement with those obtained by many investigators. Dheepa (2013) reported that $B$. megaterium was compatible with tebuconazole + trifloxystrobin at 2000 ppm. Also, B. subtilis was compatible with triazole fungicide at the same concentration (Zalte et al., 2013). B. subtilis was compatible with carbendazim, hence it used as a component in integrated disease management (Basamma and Kulkarni, 2017; Rajkumar et al., 2018). Jensen et al. (2002) evaluated the positive effects of T. harzianum and B. subtilis alone or when combined with carboxin + thiram as biological control agent treatments against the dry bean root rot pathogens. Silimela and Korsten (2001) reported that the efficiency of the bioagents could further be improved when it was applied with the recommended fungicides at their lower concentrations. Srinivas and Ramakrishnan (2002) reported that integration of bioagents and fungicides 
showed positive association by reducing the seed infection compared to fungicide and the fungal antagonists individually.

\section{CONCLUSION}

This work shows that the biological strategy which used throughout integrated pest management (IPM) could be improved by using fungicides at low rates.

\section{REFERENCES}

Akgul, D.S., Erkilic, A., 2016. Effect of wheat cultivars, fertilizers and fungicides of Fusarium foot rot disease of wheat. Turk. J. Agric. For., 40, 101-108.

Asran, M.R., El-Eraky-Amal, M.I., 2011. Aggressiveness of certain Fusarium graminearum isolates on wheat seedling and relation with their trichothecence production. Plant Pathol. J., 10 (1), 36-41.

Bagwan, N.B., 2010. Evaluation of Trichoderma compatibility with fungicides, pesticides, organic cakes and botanicals for integrated management of soil borne diseases of soybean (Glycine max L. Merrill). Int. J. Plant Prot., 3, 206-209.

Basamma, H., Kulkarni, S., 2017. Studies on compatibility of Bacillus subtilis (Ehrenberg) Cohn. With chemical fungicides. Int. J. Curr. Microbiol. Appl. Sci., 6 (3), 578586.

Bentley, A.R., Cromey, M.G., Farrokhi-Nejad, R., Leslie, J.F., Summerell, B.A., Burgess, L.W., 2006. Fusarium crown and root rot pathogens associated with wheat and grass stem bases on the South Island of New Zealand. Australas. Plant Pathol., 35 (5), 495-502.

Burlakoti, P., Rivera, V.V., Burlakoti, R.R., Nelson, R., Adhikari, T.B., Secor, G.A., Khan, M.F.R., 2010. Baseline sensitivity of Fusarium species associated with Fusarium diseases to metconazole, triticonazole, and thiabendazole fungicides. J. Sugar Beet Res., 47 (1 \& 2); 23-34.

Chaparro, A.P., Carvajaland, L.H., Orduz, S., 2011. Fungicides tolerance of Trichoderma asperelloides and $T$. harzianum strains. Agric. Sci., 2, 301-307.

Dhanya, M.K., Anjumol, K.B., Murugan, M., Deepthy, K.B., 2016. Compatibility of Trichoderma viride with Pseudomonas fluorescens with plant protection chemicals and fertilizers in cardamom. J. Trop. Agric., 54 (2),129135.

Dheepa, R., 2013. Biological and Chemical Control of White Rust (Puccinia horiana Henn) and Crown Gall (Agrobacterium tumefaciens Smith and Townsend) of Chrysanthemum under Protected Cultivation. MSc. Thesis, Tamil Nadu Agricultural University, Pudur, India.

El-Ballat, E.M.A., 2017. Efficacy of Certain Wheat Fungicides and Their Side Effects. MSc. Thesis, Fac. Agric., (Cairo), Al-Azhar University, Egypt.

El-Kholy, R.M.A., 1999. Integrated Control of Some Wheat Diseases. PhD. Thesis, Fac. Agric. (Cairo), Al-Azhar University, Egypt.
El-Sayed-Sahar, A., Abdel-Monaim, M.F., 2017. Integrated control management of root rot disease in lupine plants by using some bioagents, chemical inducers and fungicides. J. Plant Sci. Agric. Res., 1 (1-2), 1-8.

Finney, D.I. 1971. Probit analysis. Cambridge University Press, London, p.450.

Frisina, T.A., Benson, D.M. 1988. Sensitivity of binucleate Rhizoctonia spp. and R. solani to selected fungicides in vitro and on azalea under greenhouse conditions. Plant Dis., 72, 303-306.

Harman, G.E., Howell, C.R., Viterbo, A., Chet, I., Lorito, M., 2004. Trichoderma species-opportunistic, avirulent plant symbionts. Nat. Rev. Microbiol., 2, 43-56.

Ishtiaq, M., Hussain, T., Bhatti, K.H., Adesemoye, T., Maqbool, M., Azam, S., Ghani, A., 2019. Management of root rot diseases of eight wheat varieties using resistance and biological control agents techniques. Pak. J. Bot., 1 (16), 1-13.

Ivic, D., Sever, Z., Kuzmanovska, B., 2011. In vitro sensitivity of Fusarium graminearum, F. avenaceum and F.verticillioides to carbendazim, tebuconazole, flutriafol, metconazole and prochloraz. Pestic. Phytomed. (Belgrade), 26 (1), 35-42.

Jensen, C.E., Percich, J.A., Graham, P.H., 2002. Integrated management strategies of bean root rot with Bacillus subtilis and Rhizobium in Minnesota. Field Crops Res., 74, 107-115.

Knudsen, G.R., Bin, L.I., 1990. Effect of temperature, soil moisture and wheat bran on growth of Trichoderma harzianum from alginate pellets. Phytopathol., 80, 724727.

Koycu, N.D., 2018. Effect on Fusarium culmorum of fungicide used in wheat seed. International Congress on Engineering and Life Science, Proceeding Book, 2629 April, 593-601.

Kumar, V., Chaudhary, V.P., Kumar, D., Kumar, A., Sagar, S., Chaudhary, S., 2017. Efficacy of botanicals and fungicides against Rhizoctonia solani inciting sheath blight disease on rice (Oryza sativa L.). J. Appl. Nat. Sci., 9 (4), 1916-1920.

Manasa, B.G., Somashekara, Y.M., Shankara, K., Swamy, C., 2017. Efficacy of fungicides in control of Fusarium oxysporum f. sp. dianthi, the cause of wilt in carnation. Int. J. Curr. Microbiol. Appl. Sci., 6 (10), 2559-2565.

Mannai, S., Horrigue-Raouani, N., Hamdi, N.B., 2018. Effect of six fungicides against Fusarium oysporum and F. solani associated with peach seedlings decline in Tunisian nurseries. Ann. Res. Rev. Biol., 26 (4), 1-11.

Masiello, M., Somma, S., Ghionna, V., Logrieco, A.F., Moretti, A., 2019. In vitro and field response of different fungicides against Aspergillus flavus and Fusarium species causing ear rot disease of maize. Toxins, 11 (11), 1-18.

McMullen, M.P., Bradley, C.A., 2005. Field crop fungicide guide. [s.1.]: Plant Pathology Department, North Dakota State University, USA.

Miguel, T.A., Bordini, J.G., Saito, G.H., Andrade, C.G.T.J., Ono, M.A., Hirooka, E.Y., Vizoni, E., Ono, E.Y.S., 2015. Effect of fungicide on Fusarium verticillioides mycelia 
morphology and fumonisin B1 production. Braz. J. Microbiol., 46, 293-299.

Monte, E., 2001. Understanding Trichoderma: between biotechnology and microbial ecology. Int. Microbiol., 4 , 1-4.

Moubarak, M.Y.I., Abdel-Monaim, M.F., 2011. Effect of biocontrol agents on yield, yield components and root rot control in two wheat cultivars at New Valley region, Egypt. J. Cereals Oil, 2 (6), 77-87.

Naar, Z., Kecskes, M., 1998. Antagonism of Trichoderma atroviride and Trichoderma viride strains against Sclerotinia minor as influenced by mancozeb, benomyl and vinclozolin. Acta Phytopathol. Entomol. Hung., 33,123-130.

Nourozian, J., Etebarian, H.R., Khodakaramian, G., 2006. Biological control of Fusarium graminearum on wheat by antagonistic bacteria. Songklanakarin J. Sci. Technol., 28, 29-38.

Ogoshi, A., Cook, R.J., Bassett, E.N., 1990. Rhizoctonia species and anastomosis groups causing root rot of wheat and barley in the Pacific Northwest. Phytopathol., 80, 784-788.

Rajkumar, K., Naik, M.K., Chennappa, G., Amaresh, Y.S., 2018. Compatibility Bacillus subtilis (BS 16) with fungicides used in chilli ecosystem for integrated disease management. Int. J. Chem. Stud., 6 (3), 33933396.

Rubayet, T., Alam Bhuiyan, M.K., 2012. Compatibility of an isolate of Trichoderma harzianum with fungicides and organic amendments. Bang. J. Plant Pathol., 28 (1 and 2), 63-66.

Sameer, W.M., 2018. Control of the root rot diseases of wheat using fungicides alone and in combinations with selenium. Al-Azhar Bull. Sci., 29 (2), 73-83.

Silimela, M., Korsten, L., 2001. Alternative methods for preventing pre and post-harvest diseases and sunburn on mango fruits. S.A. Mango Grower Assoc. Yearbook 21,39-43.
Soovali, P., Koppel, M., Kangor, T., 2017. Effectiveness of seed treatment against Fusarium spp. and Cochliobolus sativus of spring barley in different conditions. Agron. Res., 15, 280-287.

Srinivas, P., Ramakrishnan, G., 2002. Use of native microorganisms and commonly recommended fungicides in integrated management of rice seed borne pathogens. Ann. Plant Prot. Sci., 10, 260-264.

Sriraj, P.P., Sundravadana, S., Alice, D., 2014. Efficacy of fungicides, botanicals and bioagents against Rhizoctonia solani inciting leaf blight on turmeric (Curcuma longa L.). Afr. J. Microb. Res., 8 (36), 3284-3294.

Tapwal, A., Kumar, R., Gautam, N., Pandey, S., 2012. Compatibility of Trichoderma viride for selected fungicides and botanicals. Int. J. Plant Pathol., 3 (2), 8994.

Thoudam, R., Dutta, B.K., 2014. Compatibility of Trichoderma atroviride with fungicides against black rot disease of tea: an in vitro study. J. Int. Acad. Res. Multidis., 2 (2), 25-33.

Viji, G., Manibhushanrao, K., Baby, U.I., 1997. Non-target effect of systemic fungicide on antagonistic microflora of Rhizoctonia solani. Ind. Phytopathol., 50, 324-328.

Wang, H., Chang, K., Hwang, S.F., Turnbull, G.D., Howard, R.J., Blade, S.F., Callan, N.W., 2005. Fusarium root rot of coneflower seedlings and integrated control using Trichoderma and fungicides. BioControl, 50 (2), 317-329.

Warhman, E.J., Presccott, J.M., Griffiths, E., 1989. Effectiveness of chemical seed treatments in controlling karanal bunt disease of wheat. Plant Dis., 73, 585-588.

Wedajo, B., 2015. Compatibility studies of fungicides with combination of Trichoderma species under in vitro conditions. Virol. Mycol., 4 (2), 149-153.

Zalte, A., Gade, R.M., Shitole, A.V., Belkar, Y.K., 2013. Management of tomato damping off by using plant growth promoting microorganisms. J Plant Dis. Sci., 8 (2), 200-203. 


\section{مدى توافق المركبات الحيوية مع مبيدات الفطريات في مواجهة أمراض عنن الجذور في القحح}

\section{وائل محمد سمير}

قسم وقاية النبات، كلية الزراعة، جامعة الازهر، مدينة نصر، القاهرة، مصر

Wael.sameer@azhar.edu.eg البريد الإليكتروني:

الملخص العريي

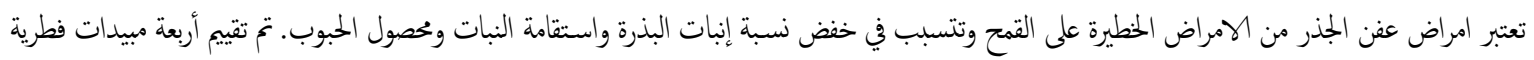

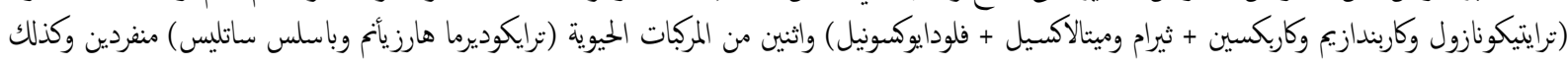

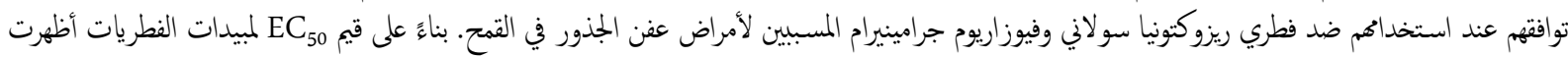

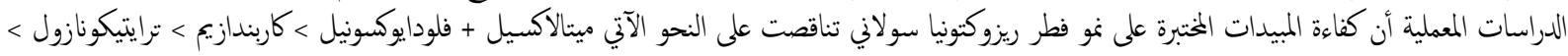

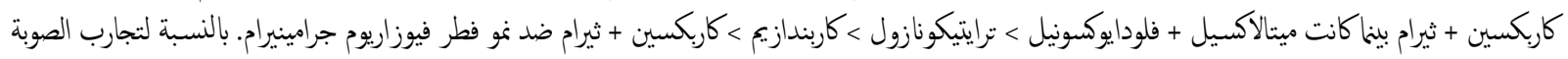

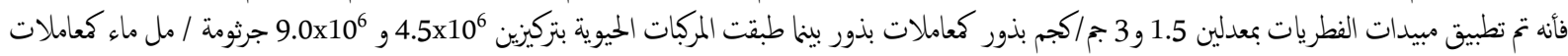

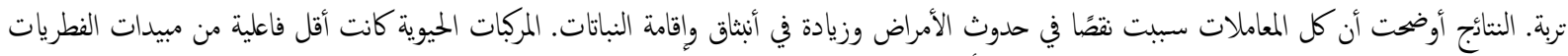

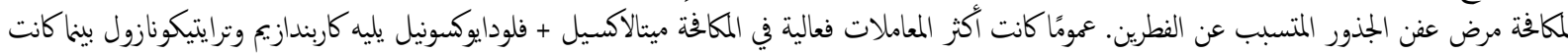

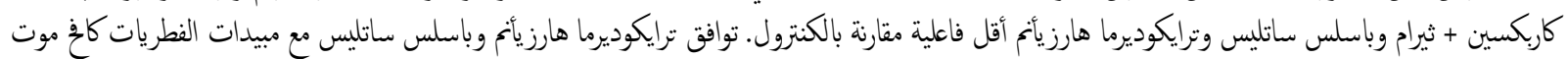

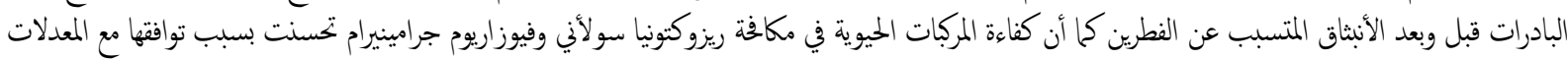
المنخفضة لمبيدات الفطريات.

$$
\text { الكلمات المفتاحية: القحح، عفن الجذور، بيزوكتونيا سولأني، فيوزاريوم جرامينيرام، مبيدات الفطريات، المركبات الحيوية. }
$$

